\title{
Complete genome sequence of the melanogenic marine bacterium Marinomonas mediterranea type strain $\left(\mathrm{MMB}-\mathbf{1}^{\mathrm{T}}\right)$.
}

Patricia Lucas-Elío', Lynne Goodwinn ${ }^{2,3}$, Tanja Woyke², Sam Pitluck², Matt Nolan ${ }^{2}$, Nikos C. Kyrpides $^{2}$, Janine C. Detter ${ }^{2}$, Alex Copeland ${ }^{2}$, Hazuki Teshima ${ }^{3}$, David Bruce ${ }^{3}$, Chris Detter ${ }^{3}$, Roxanne Tapia ${ }^{3}$, Shunsheng $\mathrm{Han}^{3}$, Miriam L. Land ${ }^{4}$, Natalia Ivanova ${ }^{2}$, Natalia Mikhailova ${ }^{2}$, Andrew W. B. Johnston ${ }^{5}$, Antonio Sanchez-Amat ${ }^{{ }^{*}}$

${ }^{1}$ Department of Genetics and Microbiology, University of Murcia, Murcia, Spain

${ }^{2}$ DOE Joint Genome Institute, Walnut Creek, California, USA

${ }^{3}$ Los Alamos National Laboratory, Bioscience Division, Los Alamos, New Mexico, USA

${ }^{4}$ Oak Ridge National Laboratory, Oak Ridge, Tennessee, USA

${ }^{5}$ School of Biological Sciences, University of East Anglia, Norwich Research Park, Norwich, UK

*Corresponding author: Antonio Sanchez-Amat (antonio@um.es)

Keywords: Gram-negative, marine, melanin, laccase, tyrosinase, lysine oxidase.

Marinomonas mediterranea MMB-1 ${ }^{\top}$ Solano \& Sanchez-Amat 1999 belongs to the family Oceanospirillaceae within the phylum Proteobacteria. This species is of interest because it is the only species described in the genus Marinomonas to date that can synthesize melanin pigments, which is mediated by the activity of a tyrosinase. M. mediterranea expresses other oxidases of biotechnological interest, such as a multicopper oxidase with laccase activity and a novel L-lysine-epsilon-oxidase. The 4,684,316 bp long genome harbors 4,228 proteincoding genes and 98 RNA genes and is a part of the Genomic Encyclopedia of Bacteria and Archaea project.

\section{Introduction}

Strain MMB $-1^{\mathrm{T}}\left(=\right.$ ATCC $700492^{\mathrm{T}}=$ CECT $\left.4803^{\mathrm{T}}\right)$ is the type strain of Marinomonas mediterranea, which belongs to the order Oceanospirillales within the class Gammaproteobacteria. The number of recognized species in the genus Marinomonas has increased in recent years and currently there are 20 species described [1-3]. M. mediterranea MMB$1^{\mathrm{T}}$ was isolated from a seawater sample $[4,5]$. Recently, it has been shown that this species forms part of the microbiota of the seagrass Posidonia oceanica [2]. In spite of the increasing number of Marinomonas species described, $M$. mediterranea has two features that have not been seen in any other species of this genus; it synthesizes melanin pigments from $L$-tyrosine, in a process catalyzed by a tyrosinase, and it expresses a multicopper oxidase with laccase activity [6,7]. Here we present a summary classification and a set of features for $M$. mediterranea $\mathrm{MMB}-1^{\mathrm{T}}$, together with the description of the complete genomic sequencing and annotation.

\section{Organism information}

M. mediterranea MMB- $1^{\mathrm{T}}$ contains seven copies of the 16S rRNA gene. Of these, four were identical to each other, and hence they were considered as representative of this species. One of the copies differs from the others by the insertion of two nucleotides. Apart from that, the seven copies only show differences in two other positions. The representative $16 \mathrm{~S}$ rRNA sequence only differs by a maximum of 4 nucleotides from the previously published 16S RNA sequence (AF063027), including two differences that correspond to ambiguous base calls. The phylogenetic neighborhood of $M$. mediterranea MMB-1 $1^{\mathrm{T}}$ in a tree based on $16 \mathrm{~S}$ rRNA sequences is shown in Figure 1. 
The cells of $M$. mediterranea MMB- $1^{\mathrm{T}}$ are generally rod-shaped with rounded ends with cell lengths and widths ranging from 1.3 to 2.0 and 0.6 to 0.7 $\mu \mathrm{m}$ respectively during exponential phase (Figure 2). Cells tend to be shorter during stationary phase. Strain MMB- $1^{\mathrm{T}}$ is motile by a single polar flagellum [9] (Table 1). Electron microscopy revealed that strain MMB-1 ${ }^{\mathrm{T}}$ synthesizes $\mathrm{R}$-bodies, which are highly organized cytoplasmic structures that are considered to be related to the presence of defective prophages $[20,21]$. On complex media, such as marine 2216 agar, colonies are brown to black, due to the synthesis of melanin pigments (4). $\mathrm{Na}^{+}$is required for growth of $M$. mediterranea MMB-1 ${ }^{\mathrm{T}}$, which can tolerate $\mathrm{NaCl}$ concentrations in the range of $1-5 \%$. The strain grows over the range of $15-30{ }^{\circ} \mathrm{C}$, is strictly aerobic and chemoorganotrophic and can hydrolyze gelatin and Tween80 but not starch. It utilizes D-glucose, Dmannose, D-fructose, sucrose, D-sorbitol, glycerol, L-glutamate, citrate, succinate, malate and acetate as carbon sources. Strain MMB- $1^{\mathrm{T}}$ is sensitive to ampicillin $(100 \mu \mathrm{g} / \mathrm{ml})$, gentamicin $(10 \mu \mathrm{g} / \mathrm{ml})$, kanamycin $(40 \mu \mathrm{g} / \mathrm{ml})$, rifampicin $(50 \mu \mathrm{g} / \mathrm{ml})$ and tetracycline $(10 \mu \mathrm{g} / \mathrm{ml})$.

\section{Genome sequencing information Genome project history}

This microorganism was selected for genome sequencing on the basis of its unique ability to express different oxidases of biotechnological interest, in particular, a multicopper oxidase with laccase activity [7]. Laccases are enzymes of interest in processes such as lignocellulose degradation and removal of xenobiotics [22]. The other oxidases are a tyrosinase involved in melanin synthesis [6] and a novel lysine- $\varepsilon$-oxidase with antimicrobial properties [23,24]. The genome comparison of this strain to Marinomonas sp MWYL1, which was shown to catabolize dimethylsulfoniopropionate (DMSP), releasing dimethyl sulfide (DMS) as one of the products [25], is also of interest.

The genome was sequenced under the Community Sequencing Program, CSP-2010 of DOE Joint Genome Institute (JGI) who performed the sequencing, finishing and annotation. The genome has been deposited in GenBank under accession number NC_015276. Table 2 presents the project information and its association with MIGS version 2.0 compliance [26].

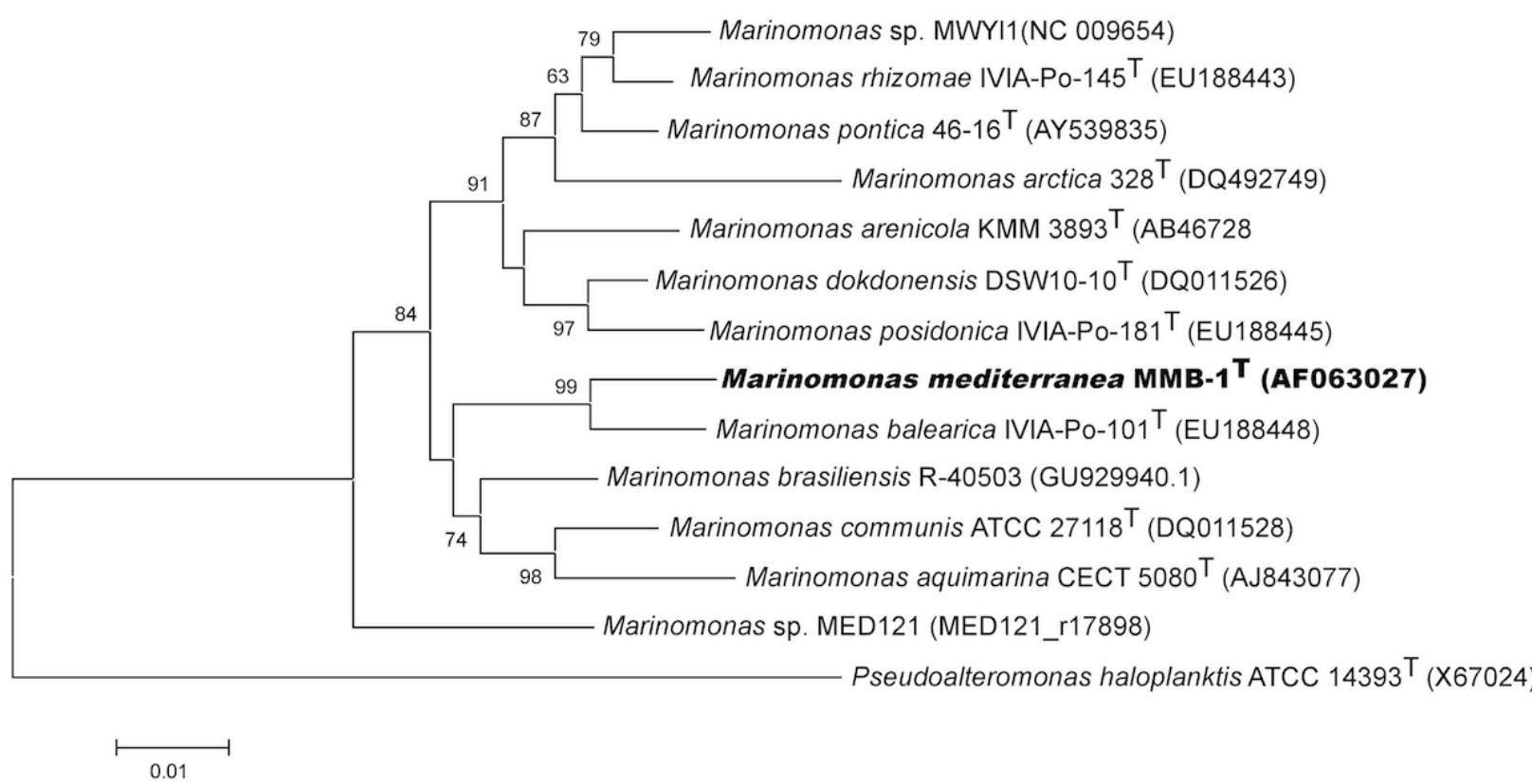

Figure 1. Phylogenetic tree highlighting the position of Marinomonas mediterranea strain MMB-1 in relation to other type (shown as ${ }^{\top}$ ) and non-type strains within the genus Marinomonas. The non-type strains are those for which genomes have been sequenced. The tree was generated using the program MEGA version 4 [8]. The sequences were aligned using the CLUSTAL W program within MEGA software. The tree was generated using the neighbor-joining method. Numbers at branches indicate bootstrap values from 1,000 replicates. P. haloplanktis (X67024) was used as an outgroup. 


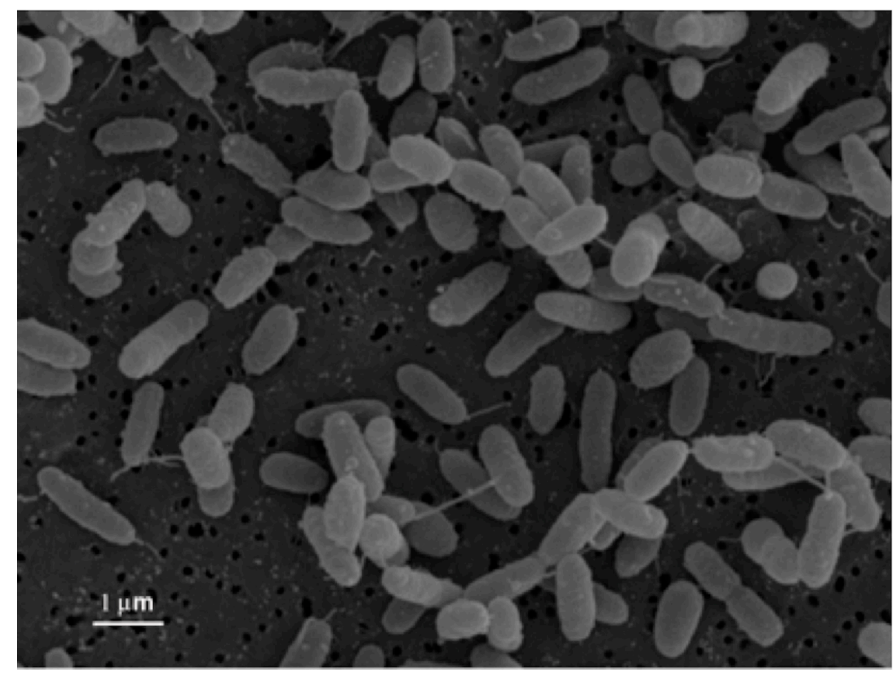

Figure 2. Scanning electron micrograph of $M$. mediterranea $M M B-1^{\top}$.

Table 1. Classification and general features of Marinomonas mediterranea MMB-1 ${ }^{\top}$ according to the MIGS recommendations.

\begin{tabular}{|c|c|c|c|}
\hline MIGS ID & Property & Term & Evidence code $^{a}$ \\
\hline & \multirow{8}{*}{ Current classification } & Domain Bacteria & TAS [10] \\
\hline & & Phylum Proteobacteria & TAS [11] \\
\hline & & Class Gammaproteobacteria & TAS $[12,13]$ \\
\hline & & Order Oceanospirillales & TAS $[12,14]$ \\
\hline & & Family Oceanospirillaceae & TAS $[12,15]$ \\
\hline & & Genus Marinomonas & TAS [16-18] \\
\hline & & Species Marinomonas mediterranea & TAS [5] \\
\hline & & Type strain $M M B-1^{\top}$ & TAS [5] \\
\hline & Gram stain & Negative & TAS [5] \\
\hline & Cell shape & Rod-shaped & TAS [5] \\
\hline & Motility & Single polar flagellum & TAS [5] \\
\hline & Sporulation & None & TAS [5] \\
\hline & Temperature range & $15^{\circ} \mathrm{C}-30^{\circ} \mathrm{C}$ & IDA \\
\hline & Optimum temperature & $25^{\circ} \mathrm{C}$ & IDA \\
\hline & Carbon source & Carbohydrates, amino acids & TAS [5] \\
\hline & Energy metabolism & Chemoorganotroph & TAS [5] \\
\hline & Terminal electron receptor & Oxygen & TAS [5] \\
\hline MIGS-6 & Habitat & Sea water & TAS [5] \\
\hline MIGS-6.3 & Salinity & $1-5 \% \mathrm{NaCl}$ & TAS [2] \\
\hline MIGS-22 & Oxygen & Aerobic & TAS [5] \\
\hline MIGS-15 & Biotic relationship & Free living and attached to Posidonia oceanica & TAS [2] \\
\hline MIGS-14 & Pathogenicity & None & TAS [5] \\
\hline MIGS-4 & Geographic location & Southeastern Spanish Mediterranean coast & TAS [4] \\
\hline MIGS-5 & Sample collection time & 1995 & IDA \\
\hline MIGS-4.1 & Latitude & Not reported & \\
\hline MIGS-4.2 & Longitude & Not reported & \\
\hline MIGS-4.3 & Depth & Not reported & \\
\hline MIGS-4.4 & Altitude & Not reported & \\
\hline
\end{tabular}

a) Evidence codes - IDA: Inferred from Direct Assay; TAS: Traceable Author Statement (i.e., a direct report exists in the literature); NAS: Non-traceable Author Statement (i.e., not directly observed for the living, isolated sample, but based on a generally accepted property for the species, or anecdotal evidence). These evidence codes are from the Gene Ontology project [19]. For the purposes of this specific publication, if the evidence code is IDA, the property was observed by one of the authors or an expert or reputable institution mentioned in the acknowledgements. 
Table 2. Project information

\begin{tabular}{lll}
\hline MIGS ID & Property & Term \\
\hline MIGS-31 & Finishing quality & Finished \\
MIGS-28 & Libraries used & $\begin{array}{l}\text { Three genomic libraries: one Illumina GAii shotgun library, one } 454 \\
\text { Titanium standard library, one paired-end 454 library }\end{array}$ \\
MIGS-29 & Sequencing platforms & Illumina GAii, 454 GS FLX Titanium \\
MIGS-31.2 & Fold coverage & $746.4 \times$ Illumina, 37.9 × 454 \\
MIGS-30 & Assemblers & Newbler version 2.3, Velvet version .7.63, phrap version SPS 4.24 \\
MIGS-32 & Gene calling method & Prodigal, GenePRIMP \\
& Genome Database release & December 20, 2010 \\
& Genbank ID & NC_015276 \\
& Genbank Date of Release & March 24, 2011 \\
& GOLD ID & Gc01696 \\
& NCBI project ID & 51765 \\
MIGS-13 & Source material identifier & ATCC 700492 \\
& Project relevance & Biotechnological, Comparative analysis, Environmental \\
\hline
\end{tabular}

\section{Growth conditions and DNA isolation}

In order to isolate quality genomic DNA for sequencing, Marinomonas mediterranea $\mathrm{MMB}-\mathrm{1}^{\mathrm{T}}$ was grown from a $-70^{\circ} \mathrm{C}$ stock in MMC agar medium [27]. A single colony was inoculated in the same broth medium and incubated overnight. This culture was used to reinoculate $200 \mathrm{ml}$ of MMC in a 2 L erlenmeyer flask, at $\mathrm{OD}_{600} 0.05$. The culture was grown at $25^{\circ} \mathrm{C}$ and $130 \mathrm{rpm}$ to the beginning of the stationary phase of growth $\left(\mathrm{OD}_{600} 0.8-0.9\right)$, then it was kept at $4{ }^{\circ} \mathrm{C}$ for 20 minutes to allow the ending of replication cycles. DNA isolation from this culture was performed using the CTAB method (Ausubel et al., 1994) with some modifications. The cells were harvested by centrifugation (6000 $\times \mathrm{g}$ ) and the pellet resuspended in $\mathrm{T}_{10} \mathrm{E}_{1} \mathrm{pH} 8$ to an $\mathrm{OD}_{600}$ of 1 . The cell suspension was treated with $0.53 \%$ SDS (Sigma) and $0.1 \mathrm{mg} / \mathrm{ml}$ Proteinase $\mathrm{K}$ (Fermentas) at $37{ }^{\circ} \mathrm{C}$ for 30 minutes. After addition of RNase A (DNase-free from Qiagen) at 0.01 $\mathrm{mg} / \mathrm{ml}$, the cells were incubated at $37^{\circ} \mathrm{C}$ for another $30 \mathrm{~min}$. In order to remove cell wall debris, denatured proteins and polysaccharides, the $\mathrm{NaCl}$ concentration was raised to $0.6 \mathrm{M}$, and $28.5 \mathrm{mM}$ of CTAB, preheated to $65^{\circ} \mathrm{C}$, was added to the cell extract followed by incubation for $10 \mathrm{~min}$ at $65^{\circ} \mathrm{C}$. CTAB-protein and CTAB-polysaccharide complexes were removed by chloroform/isoamyl alcohol (24:1), followed by phenol/chloroform/isoamyl alcohol (25:24:1) extractions. To precipitate the nucleic acids in the aqueous phase, $0.6 \mathrm{vol}$ of isopropanol were added and the sample was incu- bated for $30 \mathrm{~min}$ at room temperature. The DNA precipitate was recovered by centrifugation, followed by a $70 \%$ ethanol wash that removes residual CTAB. The DNA pellet was resuspended in TE with $0.1 \mathrm{mg} / \mathrm{ml}$ RNaseA. The suspension was kept at $-80{ }^{\circ} \mathrm{C}$ until further use.

\section{Genome sequencing and assembly}

The draft genome sequence of Marinomonas mediterranea MMB-1 was generated at the DOE Joint Genome Institute using a combination of Illumina [28] and 454 technologies [29]. For this genome, we constructed and sequenced an Illumina GAii shotgun library which generated 47,885,724 reads totaling 3,639 Mb, a 454 Titanium standard library which generated 577,566 reads and one paired-end 454 library with an average insert size of $10 \mathrm{~kb}$, which generated 356,849 reads totaling $274.9 \mathrm{Mb}$ of 454 data. All general aspects of library construction and sequencing that were performed at the JGI can be found at the JGI website [30]. The initial draft assembly contained 58 contigs in one scaffold. The 454 Titanium standard data and the 454 paired end data were assembled together with Newbler, version 2.3. The Newbler consensus sequences were computationally shredded into $2 \mathrm{~kb}$ overlapping fake reads (shreds). Illumina sequencing data were assembled with VELVET, version 0.7.63 [31], and the consensus sequences were computationally shredded into 1.5 $\mathrm{kb}$ overlapping fake reads (shreds). We integrated the 454 Newbler consensus shreds, the Illumina 
VELVET consensus shreds and the read pairs in the 454 paired-end library using parallel phrap, version SPS - 4.24 (High Performance Software, LLC). The software Consed [32-34] was used in the following finishing process. Illumina data were used to correct potential base errors and increase consensus quality using the software Polisher developed at JGI (Alla Lapidus, unpublished). Possible mis-assemblies were corrected using gapResolution (Cliff Han, unpublished), Dupfinisher [35], or by sequencing cloned bridging PCR fragments with sub-cloning. Gaps between contigs were closed by editing in Consed, by PCR and by Bubble PCR (J-F Cheng, unpublished) primer walks. A total of 159 additional reactions were necessary to close gaps and to raise the quality of the finished sequence. The total size of the genome is $4,684,316 \mathrm{bp}$ and the final assembly is based on $178 \mathrm{Mb}$ of 454 draft data, which provide an average $37.9 \times$ coverage of the genome and 3,508 Mb of Illumina draft data which provide an average $746.4 \times$ coverage of the genome.

\section{Genome annotation}

Genes were identified using Prodigal [36] as part of the Oak Ridge National Laboratory genome annotation pipeline, followed by a round of manual curation using the JGI GenePRIMP pipeline [37]. The predicted CDSs were translated and used to search the National Center for Biotechnology Information (NCBI) non-redundant database, UniProt, TIGRFam, Pfam, PRIAM, KEGG, COG, and InterPro databases. These data sources were combined to assert a product description for each predicted protein. Non-coding genes and miscellaneous features were predicted using tRNAscanSE [38], RNAMMer [39], Rfam [40], TMHMM [41], and signalP [42]. Further comparative analysis was performed using the IMG-ER system [43].

\section{Genome properties}

The genome has no plasmids, and the 4,684,316 bp circular chromosome has a GC content of $44.13 \%$ (Table 3 and Figure 3). Of the 4,326 predicted genes, 4,228 were protein-coding genes, and 98 RNAs; 105 pseudogenes were also identified. The majority of the protein-coding genes (73\%) were assigned with a putative function while those remaining were annotated as hypothetical proteins. The distribution of genes into COGs functional categories is presented in Table 4.

Table 3. Genome statistics

\begin{tabular}{|c|c|c|}
\hline Attribute & Value & $\%$ of total ${ }^{a}$ \\
\hline Genom size (bp) & $4,684,316$ & 100 \\
\hline DNA coding region (bp) & $4,084,912$ & 87.20 \\
\hline DNA G+C content (bp) & $2,067,071$ & 44.13 \\
\hline Number of replicons & 1 & \\
\hline Extrachromosomal elements & 0 & \\
\hline Total genes & 4,326 & 100.00 \\
\hline Pseudogenes $^{b}$ & 105 & 2.43 \\
\hline RNA genes & 98 & 2.27 \\
\hline rRNA operons & 7 & \\
\hline Protein-coding genes & 4,228 & 97.73 \\
\hline Genes with function prediction & 3,158 & 73.00 \\
\hline Genes in paralog clusters & 2,055 & 47.50 \\
\hline Genes assigned to COGs & 3,408 & 78.78 \\
\hline Genes assigned in Pfam domains & 3,460 & 79.98 \\
\hline Genes with signal peptides & 825 & 19.07 \\
\hline Genes with transmembrane helices & 979 & 22.63 \\
\hline CRISPR repeats & 4 & \\
\hline
\end{tabular}

a) The total is based on either the size of the genome in base pairs or the total number of protein coding genes in the annotated genome.

b) Pseudogenes may also be counted as protein-coding or RNA genes, so are not additive under total gene count. 


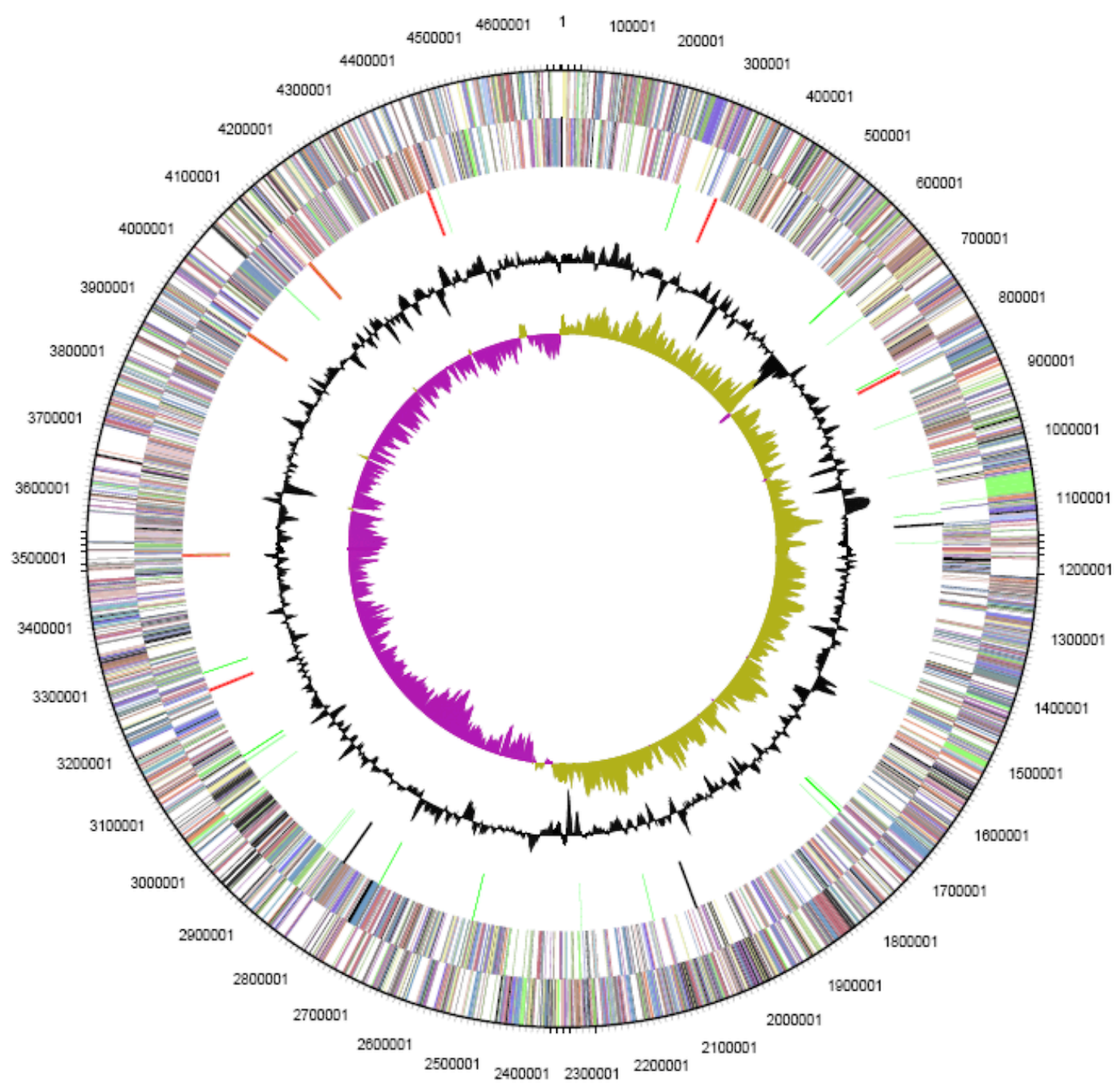

Figure 3. Graphical circular map of the chromosome. From outside to the center: genes on forward strand (color by COG categories), genes on reverse strand (color by COG categories) RNA genes (tRNAs green, rRNAs red, other RNAs black), GC content, GC skew.

\section{Insights from genome sequence}

The genome sequence of strain MMB-1 ${ }^{\mathrm{T}}$ revealed some interesting features in relation to its known enzymatic activities of biotechnological interest. There was one copy of an operon responsible for melanin synthesis from $L$-tyrosine [6]. The genes forming part of this operon are Marme_3962, encoding a tyrosinase (PpoB1), and Marme_3961, which encodes a membrane protein (PpoB2) involved in copper delivery to the tyrosinase [44]. BLAST-based searches using the sequence of this $M$. mediterranea tyrosinase against the Proteobacteria deposited in IMG as of Sept 2011 retrieved only 18 hits at a cutoff value of $<\mathrm{e}^{-20}$. Among those hits, only one was from another Gammaproteobacteria, namely the product of the HCH_03392 gene from
Hahella chejuensis KCTC2396, which was 45\% identical at the polypeptide level to the $M$. mediterranea PpoB1 enzyme. Interestingly, genes whose products closely resemble those of Marme_3962 and Marme_3961 are also found adjacent to each other in Hahella chejuensis (genes HCH_03392 and HCH_03391) as well as in several distantly related bacteria, including Rhizobium vitis (Agrobacterium vitis) S4 (genes Avi_2427 and Avi_2428) and Citreicella sp. SE45 (genes CSE45_2624 and CSE45_2624), both of which are in the Alphaproteobacteria. This suggests that the operon encoding the tyrosinase and its chaperone have been transferred by horizontal genetic transfer mechanisms. 
Table 4. Number of genes associated with the 25 general COG functional categories.

\begin{tabular}{crrl}
\hline Code & Value & \%age & Description \\
\hline J & 185 & 4.8 & Translation, ribosomal structure and biogenesis \\
A & 1 & 0.03 & RNA processing and modification \\
K & 327 & 8.48 & Transcription \\
L & 181 & 4.69 & Replication, recombination and repair \\
B & 3 & 0.08 & Chromatin structure and dynamics \\
D & 39 & 1.01 & Cell cycle control, cell division and chromosome partitioning \\
Y & 0 & 0 & Nuclear structure \\
V & 28 & 0.73 & Defense mechanisms \\
T & 311 & 8.07 & Signal transduction mechanisms \\
M & 187 & 4.85 & Cell wall/membrane/envelope biogenesis \\
N & 129 & 3.35 & Cell motility \\
Z & 0 & 0.0 & Cytoskeleton \\
W & 0 & 0.0 & Extracellular structures \\
U & 97 & 2.52 & Intracellular trafficking, secretion and vesicular transport \\
O & 135 & 3.5 & Post-translational modification, protein turnover, chaperones \\
C & 192 & 4.98 & Energy production and conversion \\
G & 215 & 5.58 & Carbohydrate transport and metabolism \\
E & 401 & 10.4 & Amino acid transport and metabolism \\
F & 81 & 2.1 & Nucleotide transport and metabolism \\
H & 165 & 4.28 & Coenzyme transport and metabolism \\
I & 117 & 3.03 & Lipid transport and metabolism \\
P & 187 & 4.85 & Inorganic ion transport and metabolism \\
Q & 132 & 3.42 & Secondary metabolites biosynthesis, transport and catabolism \\
R & 425 & 11.02 & General function prediction only \\
S & 318 & 8.25 & Function unknown \\
- & 918 & 21.22 & Not in COGs \\
\hline & & &
\end{tabular}

Regarding $L$-tyrosine metabolism, the annotation of the genome of $M$. mediterranea revealed genes encoding proteins involved in tyrosine degradation. Two of those genes (Marme_3331 and Marme_4181) encode putative transaminases, which could generate p-hydroxyphenylpyruvate. Interestingly, the catabolic route from this compound is incomplete, which could explain why $M$. mediterranea can use $L$-tyrosine as nitrogen source, but not as a sole carbon source [45].

In addition to the tyrosinase, another polyphenol oxidase of biotechnological interest, PpoA, is expressed by $M$. mediterranea. PpoA is a multicopper oxidase with laccase activity [7] and is encoded by the gene Marme_0056. A BLAST-based search using the sequence of this protein, with a cutoff value of $\mathrm{e}^{-}$ 20 , revealed several homologues in different proteobacteria, including 17 hits (out of 678 ge- nomes) within the Gammaproteobacteria. Interestingly, the three strains mentioned above $(H$. chejuensis KCTC2396, $R$. vitis S4 and Citreicella sp. SE45) in which the tyrosinase operon was conserved, also contain genes encoding proteins similar to PpoA. However, genome analysis does not offer indications of possible co-transfer of both genes since $p p o A$-like genes are not close to $p p o B$ like genes in any of the genomes analyzed.

The genome of $M$. mediterranea also contains a locus, Marme_2975, encoding a protein with 31.9\% identity to the protein RL5, described as possessing laccase activity, which was detected from a metagenomic library [46]. In the case of $M$. mediterranea, a mutation in the gene Marme_0056 abolishes laccase activity in all the conditions studied [47], so the possible laccase activity of the product of Marme_2975 remains to be determined. 
In this regard, we note that homologues of Marme_2975 also occur in the other Marinomonas strains that have been sequenced: $M$. posidonica IVIA-Po-181 ${ }^{\mathrm{T}}$ (Mar181_0693), Marinomonas sp. MED 121 (MED121_05683) and Marinomonas sp. MWYL1 (Mmwyl1_3610), which do not show laccase activity (Sanchez-Amat, unpublished observations).

An enzyme (LodA) with $L$-lysine-epsilon oxidase activity (E.C:1.4.3.20) was described for the first time in $M$. mediterranea (14). The gene (Marme_2662) encoding this enzyme forms part of an operon with lodB (Marme_2661), which encodes a protein of unknown function but is required for expression of LodA [48]. LodA is an unusual $L^{-}$ amino acid oxidase (LAO), since it is a quinoprotein and does not contain FAD as cofactor, unlike most other LAOs. When the sequence of LodA was used as a query against the genomes of Proteobacteria in IMG, 22 hits to gene products in different classes of bacteria were detected with a cutoff value of $<\mathrm{e}^{-20}$. Interestingly, it was clear that M. mediterranea itself had two additional genes (respectively Marme_2396 and Marme_1655) that encoded polypeptides that resembled LodA, being respectively $23.3 \%$ and $24.4 \%$ identical to it. The products of three genes in the NCBI database of bacterial genomes (Mmwyl1_3721 of Marinomonas sp. MWYL1, PTD2_20217 (alpP) of Pseudoalteromonas tunicata D2 and Nhal_1019 of "Nitrosococcus halophilus" Nc4) were extremely similar in sequence ( $\mathrm{E}$ value of 0 ) to LodA of $M$. mediterranea, strongly indicating that these, too, encode enzymes with L-lysine oxidase activity. In fact, this has been experimentally demonstrated for one of these, namely AlpP of P. tunicata [49]. A preliminary

\section{Acknowledgments}

The work conducted by the U.S. Department of Energy Joint Genome Institute is supported by the Office of Science of the U.S. Department of Energy under Contract No. DE-AC02-05CH11231. Work on Marinomonas

\section{References}

1. Chimetto LA, Cleenwerck I, Brocchi M, Willems A, De VP, Thompson FL. Marinomonas brasilensis sp. nov., isolated from the coral Mussismilia hispida, and reclassification of Marinomonas basaltis as a later heterotypic synonym of Marinomonas communis. Int / Syst Evol Microbiol $2011 ; 61: 1170-1175$. PubMed http://dx.doi.org/10.1099/ijs.0.024661-0 screening of all those genes similar to $\operatorname{lod} A$ in $M$. mediterranea and other bacteria revealed that they also form part of an operon containing a gene similar to $\operatorname{lod} B$.

In relation to $L$-lysine metabolism, it is also of interest that up to 14 genes encode proteins annotated as lysine exporter proteins (LYSE/YGGA). This property could be related to the extracellular activity of the $L$-lysine oxidase that oxidizes $L$-lysine, generating hydrogen peroxide, which participates in cell death during biofilm development [49]. Genome analysis of strain MMB-1 indicates that it contains all the enzymes required for $L$-lysine biosynthesis. Although $M$. mediterranea cannot use $L$ lysine as sole carbon and energy source, it can use this amino acid as nitrogen source even in mutants lacking LodA activity $[45,48]$. Therefore, there must be some other enzymatic activities involved in nitrogen assimilation from $L$-lysine, but genome analysis has not revealed their identity.

Another strain of this genus, namely Marinomonas sp. MWYL1, was shown to grow at the expense of DMSP, an abundant intracellular compatible solute that is made by many marine phytoplankton. One of the products was DMS, an environmentally important gas that can affect climate. The enzyme that generated the DMS from DMSP was encoded by the gene $d d d D$ (Mmwyl1_4041) [25], and a very close homologue (the protein products are $80 \%$ identical) was found in the genome of $M$. mediterranea MMB-1 (Marme_2354). In addition, the organization of other genes involved in the import of DMSP and some of the downstream catabolic steps were also conserved in their locations and their sequences in the two Marinomonas strains.

mediterranea was supported by several grants from the Spanish Ministerio de Ciencia e Innovación (Current project BIO2010-15226) and the Fundación Séneca (CARM, Spain) (Current project 11867/PI/09).

2. Espinosa E, Marco-Noales E, Gomez D, LucasElio P, Ordax M, Garcias-Bonet N, Duarte CM, Sanchez-Amat A. Taxonomic study of Marinomonas strains isolated from the seagrass Posidonia oceanica, with descriptions of Marinomonas balearica sp. nov. and Marinomonas pollencensis sp. nov. Int J Syst Evol Microbiol 2010; 60:93-98. PubMed http://dx.doi.org/10.1099/ijs.0.008607-0 
Lucas-Elio et al.

3. Lucas-Elío P, Marco-Noales E, Espinosa E, Ordax M, Lopez MM, Garcias-Bonet N, Marba N, Duarte CM, Sanchez-Amat A. Marinomonas alcarazii sp. nov., M. rhizomae sp. nov., M. foliarum sp. nov., $M$. posidonica sp. nov. and $M$. aquiplantarum sp. nov., isolated from the microbiota of the seagrass Posidonia oceanica. Int J Syst Evol Microbiol 2011; 61:2191-2196. PubMed http://dx.doi.org/10.1099/ijs.0.027227-0

4. Solano F, García E, Pérez de Egea E, SanchezAmat A. Isolation and characterization of strain MMB-1 (CECT 4803), a novel melanogenic marine bacterium. Appl Environ Microbiol 1997; 63:3499-3506. PubMed

5. Solano F, Sanchez-Amat A. Studies on the phylogenetic relationships of melanogenic marine bacteria: proposal of Marinomonas mediterranea sp. nov. Int J Syst Bacteriol 1999; 49:1241-1246. PubMed http://dx.doi.org/10.1099/00207713-49$\underline{3-1241}$

6. López-Serrano D, Solano F, Sanchez-Amat A. Identification of an operon involved in tyrosinase activity and melanin synthesis in Marinomonas mediterranea. Gene 2004; 342:179-187. PubMed http://dx.doi.org/10.1016/j.gene.2004.08.003

7. Sanchez-Amat A, Lucas-Elio P, Fernández E, Garcia-Borrón JC, Solano F. Molecular cloning and functional characterization of a unique multipotent polyphenol oxidase from Marinomonas mediterranea. Biochim Biophys Acta 2001; 1547:104-116. PubMed http://dx.doi.org/10.1016/S0167-4838(01)001741

8. Tamura K, Dudley J, Nei M, Kumar S. MEGA4: Molecular Evolutionary Genetics Analysis (MEGA) software version 4.0. Mol Biol Evol 2007;

24:1596-1599. PubMed http://dx.doi.org/10.1093/molbev/msm092

9. Sanchez-Amat A, Solano F. Genus III. Marinomonas Van Landschoot and De Ley 1984, $91^{\mathrm{VP}}$ (Effective publication Van Lanschoot and De Ley 1983, 3071). Bergey's Manual of Systematic Bacteriology, second edition. Edited by Brenner DJ, Krieg NR, Staley JT, and Garrity GM. New York, Springer, 2005, pp. 284-289

10. Woese CR, Kandler O, Wheelis ML. Towards a natural system of organisms: proposal for the domains Archaea, Bacteria, and Eucarya. Proc Natl Acad Sci USA 1990; 87:4576-4579. PubMed http://dx.doi.org/10.1073/pnas.87.12.4576

11. Garrity GM, Bell JA, Lilburn T. Phylum XIV. Proteobacteria phyl. nov. In: Garrity GM, Brenner
DJ, Krieg NR, Staley JT (eds), Bergey's Manual of Systematic Bacteriology, Second Edition, Volume 2, Part B, Springer, New York, 2005, p. 1.

12. List Editor. Validation of publication of new names and new combinations previously effectively published outside the IJSEM. List no. 106. Int J Syst Evol Microbiol 2005; 55:2235-2238. http://dx.doi.org/10.1099/ijs.0.64108-0

13. Garrity GM, Bell JA, Lilburn T. Class III. Gammaproteobacteria class. nov. In: Garrity GM, Brenner DJ, Krieg NR, Staley JT (eds), Bergey's Manual of Systematic Bacteriology, Second Edition, Volume 2, Part B, Springer, New York, 2005, p. 1.

14. Garrity GM, Bell JA, Lilburn T. Order VIII. Oceanospirillales ord. nov. In: Garrity GM, Brenner DJ, Krieg NR, Staley JT (eds), Bergey's Manual of Systematic Bacteriology, Second Edition, Volume 2, Part B, Springer, New York, 2005, p. 270.

15. Garrity GM, Bell JA, Lilburn T. Family I. Oceanospirillaceae fam. nov. In: Garrity GM, Brenner DJ, Krieg NR, Staley JT (eds), Bergey's Manual of Systematic Bacteriology, Second Edition, Volume 2, Part B, Springer, New York, 2005, p. 271.

16. List Editor. Validation List no. 13. Validation of the publication of new names and new combinations previously effectively published outside the IJSB. Int J Syst Bacteriol 1984; 34:91-92. http://dx.doi.org/10.1099/00207713-34-1-91

17. van Landschoot A, De Ley J. Intra- and intergeneric similarities of the rRNA cistrons of Alteromonas, Marinomonas, gen. nov. and some other Gram-negative bacteria. J Gen Microbiol 1983; 129:3057-3074.

18. Espinosa E, Marco-Noales E, Gómez D, LucasElío P, Ordax M, Garcías-Bonet N, Duarte CM, Sanchez-Amat A. Taxonomic study of Marinomonas strains isolated from the seagrass Posidonia oceanica, with descriptions of Marinomonas balearica sp. nov. and Marinomonas pollencensis sp. nov. Int J Syst Evol Microbiol 2010; 60:93-98. PubMed http://dx.doi.org/10.1099/ijs.0.008607-0

19. Ashburner M, Ball CA, Blake JA, Botstein D, Butler H, Cherry JM, Davis AP, Dolinski K, Dwight SS, Eppig JT, et al. Gene ontology: tool for the unification of biology. The Gene Ontology Consortium. Nat Genet 2000; 25:25-29. PubMed http://dx.doi.org/10.1038/75556

20. Hernández-Romero D, Lucas-Elio P, LopezSerrano D, Solano F, Sanchez-Amat A. 
Marinomonas mediterranea is a lysogenic bacterium that synthesizes R-bodies. Microbiology

2003; 149:2679-2686. PubMed

http://dx.doi.org/10.1099/mic.0.26524-0

21. Sanchez-Amat A. R-bodies. Inclusion in Prokaryotes. Edited by Shively JM. Berlin, Springer-

Verlag, 2006, pp. 331-341

22. Riva S. Laccases: blue enzymes for green chemistry. Trends Biotechnol 2006; 24:219-226. PubMed

http://dx.doi.org/10.1016/j.tibtech.2006.03.006

23. Gómez D, Lucas-Elio P, Sanchez-Amat A, Solano F. A novel type of lysine oxidase: L-lysine-epsilonoxidase. Biochim Biophys Acta 2006; 1764:15771585. PubMed

24. Lucas-Elío P, Gomez D, Solano F, Sanchez-Amat A. The antimicrobial activity of marinocine, synthesized by Marinomonas mediterranea, is due to hydrogen peroxide generated by its lysine oxidase activity. I Bacteriol 2006; 188:2493-2501. PubMed http://dx.doi.org/10.1128//B.188.7.24932501.2006

25. Todd JD, Rogers R, Li YG, Wexler M, Bond PL, Sun L, Curson AR, Malin G, Steinke M, Johnston AWB. Structural and regulatory genes required to make the gas dimethyl sulfide in bacteria. Science 2007; 315:666-669. PubMed http://dx.doi.org/10.1126/science.1135370

26. Field D, Garrity G, Gray T, Morrison N, Selengut J, Sterk P, Tatusova T, Thomson N, Allen MJ, Angiuoli SV, et al. I, Wilson G, and Wipat A: The minimum information about a genome sequence (MIGS) specification. Nat Biotechnol 2008;

26:541-547. PubMed http://dx.doi.org/10.1038/nbt1360

27. Fernández E, Sanchez-Amat A, Solano F. Location and catalytic characteristics of a multipotent bacterial polyphenol oxidase. Pigment Cell Res 1999; 12:331-339. PubMed http://dx.doi.org/10.1111/j.16000749.1999.tb00767.x

28. Bennett S. Solexa Ltd. Pharmacogenomics 2004; 5:433-438. PubMed http://dx.doi.org/10.1517/14622416.5.4.433

29. Margulies $M$, Egholm M, Altman WE, Attiya $S$, Bader JS, Bemben LA, Berka J, Braverman MS, Chen YJ, Chen Z, et al. Genome sequencing in microfabricated high-density picolitre reactors. Nature 2005; 437:376-380. PubMed

30. DOE Joint Genome Institute. http://www.jgi.doe.gov
31. Zerbino DR, Birney E. Velvet: algorithms for de novo short read assembly using de Bruijn graphs. Genome Res 2008; 18:821-829. PubMed http://dx.doi.org/10.1101/gr.074492.107

32. Ewing B, Hillier L, Wendl MC, Green P. Basecalling of automated sequencer traces using phred. I. Accuracy assessment. Genome Res 1998; 8:175-185. PubMed

33. Ewing B, Green P. Base-calling of automated sequencer traces using phred. II. Error probabilities. Genome Res 1998; 8:186-194. PubMed

34. Gordon D, Abajian C, Green P. Consed: a graphical tool for sequence finishing. Genome Res 1998; 8:195-202. PubMed

35. Han C, Chain P. Finishing repeat regions automatically with Dupfinisher. Proceeding of the 2006 International Conference on bioinformatics and computational biology, pp 141-146.

36. Hyatt $\mathrm{D}$, Chen $\mathrm{GL}$, Locascio PF, Land ML, Larimer FW, Hauser LJ. Prodigal: prokaryotic gene recognition and translation initiation site identification. BMC Bioinformatics 2010; 11:119. PubMed http://dx.doi.org/10.1186/1471-2105-11-119

37. Pati A, Ivanova NN, Mikhailova N, Ovchinnikova G, Hooper SD, Lykidis A, Kyrpides NC. GenePRIMP: a gene prediction improvement pipeline for prokaryotic genomes. Nat Methods 2010; 7:455-457. PubMed http://dx.doi.org/10.1038/nmeth.1457

38. Lowe TM, Eddy SR. tRNAscan-SE: a program for improved detection of transfer RNA genes in genomic sequence. Nucleic Acids Res 1997; 25:955-964. PubMed http://dx.doi.org/10.1093/nar/25.5.955

39. Lagesen K, Hallin P, Rodland EA, Staerfeldt HH, Rognes T, Ussery DW. RNAmmer: consistent and rapid annotation of ribosomal RNA genes. Nucleic Acids Res 2007; 35:3100-3108. PubMed http://dx.doi.org/10.1093/nar/gkm160

40. Griffiths-Jones S, Bateman A, Marshall M, Khanna A, Eddy SR. Rfam: an RNA family database. Nucleic Acids Res 2003; 31:439-441. PubMed http://dx.doi.org/10.1093/nar/gkg006

41. Krogh A, Larsson B. von HG, and Sonnhammer EL: Predicting transmembrane protein topology with a hidden Markov model: application to complete genomes. J Mol Biol 2001; 305:567580. PubMed http://dx.doi.org/10.1006/jmbi.2000.4315

42. Bendtsen JD, Nielsen $\mathrm{H}$. von $\mathrm{HG}$, and Brunak S: Improved prediction of signal peptides: SignalP 
3.0. J Mol Biol 2004; 340:783-795. PubMed

http://dx.doi.org/10.1016/j.jmb.2004.05.028

43. Markowitz VM, Mavromatis K, Ivanova NN, Chen IM, Chu K, Kyrpides NC. IMG ER: a system for microbial genome annotation expert review and curation. Bioinformatics 2009; 25:2271-2278.

PubMed

http://dx.doi.org/10.1093/bioinformatics/btp393

44. López-Serrano D, Solano F, Sanchez-Amat A. Involvement of a novel copper chaperone in tyrosinase activity and melanin synthesis in Marinomonas mediterranea. Microbiology 2007; 153:2241-2249. PubMed http://dx.doi.org/10.1099/mic.0.2007/006833-0

45. Molina-Quintero LR, Lucas-Elio P, Sanchez-Amat A. Regulation of the Marinomonas mediterranea antimicrobial protein lysine oxidase by L-lysine and the sensor histidine kinase PpoS. Appl Environ Microbiol 2010; 76:6141-6149. PubMed http://dx.doi.org/10.1128/AEM.00690-10

46. Beloqui A, Pita M, Polaina J, Martinez-Arias A, Golyshina OV, Zumarraga M, Yakimov MM, Garcia-Arellano H, Alcalde M, Fernandez VM, et al. Novel polyphenol oxidase mined from a metagenome expression library of bovine rumen: biochemical properties, structural analysis, and phylogenetic relationships. I Biol Chem 2006; 281:22933-22942. PubMed http://dx.doi.org/10.1074/jbc.M600577200

47. Solano F, Lucas-Elío P, Fernández E, SanchezAmat A. Marinomonas mediterranea MMB-1 transposon mutagenesis: Isolation of a multipotent polyphenol oxidase mutant. / Bacteriol 2000; 182:3754-3760. PubMed http://dx.doi.org/10.1128/JB.182.13.3754$\underline{3760.2000}$

48. Gómez D, Lucas-Elio P, Solano F, Sanchez-Amat A. Both genes in the Marinomonas mediterranealod $A B$ operon are required for the expression of the antimicrobial protein lysine oxidase. Mol Microbiol 2010; 75:462-473. PubMed http://dx.doi.org/10.1111/j.13652958.2009.07000.x

49. Mai-Prochnow A, Lucas-Elio P, Egan $\mathrm{S}$, Thomas $\mathrm{T}$, Webb JS, Sanchez-Amat A, Kjelleberg S. Hydrogen peroxide linked to lysine oxidase activity facilitates biofilm differentiation and dispersal in several Gram-negative bacteria. I Bacteriol 2008; 190:5493-5501. PubMed http://dx.doi.org/10.1128//B.00549-08 